\title{
Dialogic supervision: Investigating supervision practices of English pre-service teachers in a professional training program (PLP)
}

\author{
R. Della Nuridah Kartika Sari Amirulloh*, Nenden Sri Lengkanawati, and Sri Setyarini \\ Department of English Education, Faculty of Language and Literature Education, Universitas Pendidikan Indonesia, \\ Jl. Dr. Setiabudhi No. 229, Bandung, West java, Indonesia
}

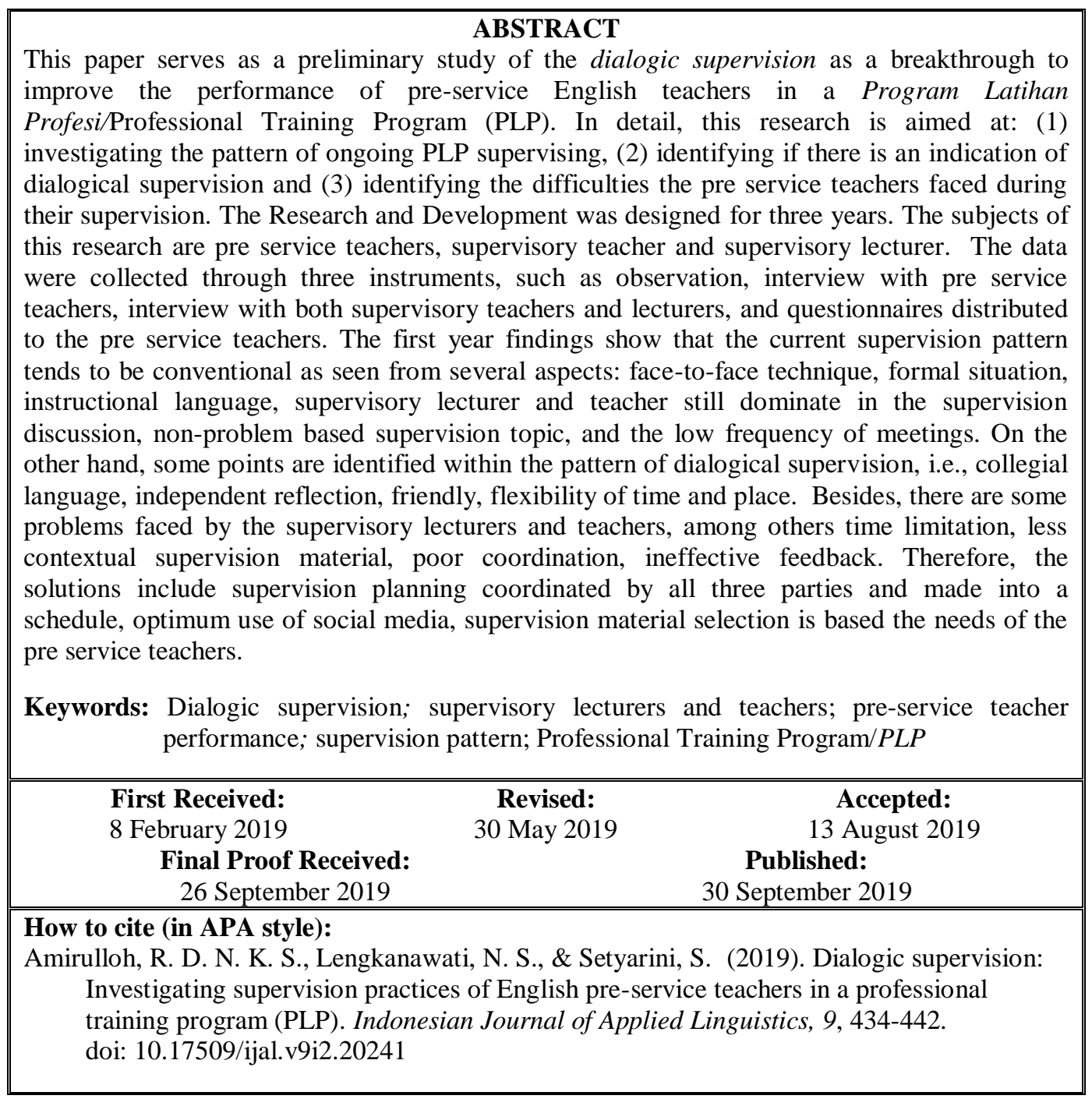

\section{INTRODUCTION}

PLP (Program Latihan Profesi/Professional Training Program) - or previously known as PPL (Program Praktik Lapangan/Field Practice Program) - is one of the compulsory unit offered by the English Department for the $8^{\text {th }}$ semester students. PLP aims to provide opportunities for the students to engage with the field of discipline (professional competence) and to perform the professional competence within the learning process (pedagogical competence) (Sujati, 2015). However, the implementation of PLP has not been effective for several reasons: 1) The program is generally viewed as a mere mandatory annual program for education student; (2) The majority of the stakeholders rarely critically examine the practices of PLP and are most likely to adhere with the system. As a result, the

\footnotetext{
* Corresponding Author

Email: della@upi.edu
} 
program has failed to assist students to attain the necessary skills. Lack of coordination and the apparently standard one way monitoring of PLP have been recognized as the major cause. Therefore, PLP should be geared towards a new supervision model that caters the needs of both supervisors and students to achieve the program objectives.

Considering the situation, this research emphasizes on the needs to revitalize the PLP to be more dialogical in its practices, that is a supervisory model that can be accomplished through multiple models - either between the supervisory teacher/lecturer and the pre service teacher, the supervisory lecturer and the supervisory teacher, or the collaboration of all three parties. The systematic changes in organising the PLP leads to the development of an open, critical, and two-way-oriented communication between the PLP components. Therefore, all of the parties obtain a thorough and comprehensive picture of the school conditions. Relevant with that, the research specifically endeavours to 1) investigate the supervision pattern of English Education PLP; 2) identify whether the dialogical based supervision is found within the existing supervision; 3) identify the difficulties faced by all of the three parties (supervisory teacher, pre service teacher, and supervisory lecturer) in organising the PLP supervision and to identify the strategy undertaken to solve the problem.

The findings of this research can serve as a recommendation for future implementation and supervision model emphasizing on the need of implementing the dialogic supervision in the program.

\section{Program Latihan Profesi/Professional Training Program (PLP)}

Program Latihan Profesi/Professional Training Program (PLP) is one of the university-established programs incorporated into the curriculum. The program is mandatory for all fourth year college learners (semester 7 or 8) to enforce the understanding they acquired during their lessons. The program also assists the students to recognise and prepare for the classroom setting and the existing phenomena that occurred in the school environment before they become a real teacher. Assuming that the performance of quality teachers is parallel to a quality teaching learning process, the country sets high expectations in them to help create a better nation. Therefore, teacher education program must provide the students with quality teaching that covers pedagogical, social, personal, professional competences.

Specifically, PLP is a program designed to train the students of Teacher Training and Education Undergraduate Program to master teaching competence to be prepared to conduct their task as professional teachers. PLP serves as a site for students to practice performing their professional competence in a real scenario, programmed, participatory and systematically monitored in partner schools. Based on the definition of PLP, the core activity is the following:
1. directing learners to master the practical experience of educational skills and learning foundations in classrooms;

2. conducting the PLP in partner schools that have fulfilled standard criteria, management, culture, and prospective educational climate for supervisory teachers;

3. conducting the PLP monitoring and supervising that ensures mastery accomplishment for teacher training and undergraduate students' academic skills.

4. providing integrated oversight by the supervisory lecturer and teacher to ensure the teacher training students' mastery of academic competence.

The general objectives of the Undergraduate Program's PLP for Teacher Training and Education are to reinforce the mastery of academic skills, develop the professional identity as an educator and also prepare basic experiences in educational learning under the effective supervision of both supervisory lecturer and supervisory teacher. Specifically, the objectives of the PLP for the Education Undergraduate Program for the students are the following:

1. Recognise the characteristics of the learners from the perspectives of developmental stages and individual differences;

2. Observe physical, geographical and social environment of the school partners;

3. Review the Content Standards (SI) and Graduate Competence Standards (SKL), and also the curriculum/syllabus developed by the teachers at the partner schools;

4. Observe the learning activity;

5. Review material, method, media, and the teaching sources used by the teacher;

6. Recognise the organisational structure and school management;

7. Review the process and the learning grading results of the students made by the teacher;

8. Develop Rancangan Pelaksanaan Pembelajaran/Lesson Plan (RPP) of the subjects taught;

9. Implement the RPP/Lesson Plan in order to provide learning instructions with the supervision of both supervisory lecturer and supervisory teacher;

10. Analyse and follow-up the process and the result of the learners' learning evaluation.

PLP pattern for teacher training and education must therefore be properly concentrated on mastering academic competence as well as developing professional identity. Students are expected to observe, review, and communicate aspects of learning in classrooms. However, to provide practical knowledge as the grounds for further skills development, the PLP for Bachelors of Teacher Training and Education still requires to be systematically programmed and enforced. 
This is because not all Bachelor of Teacher Training and Education graduates have the same opportunities to pursue further studies at a PPG program or a degree in higher education.

\section{Dialogic Supervision}

Dialogic supervision is a type of supervision to improve and develop an individual's professionalism in education organisation, where communication occurs through face-to-face interaction (Glanz \& Horenstein, 2000). Undoubtedly, a supervision activity is a key agenda for educational organization. Porniadi, et.al (2019) argues that a supervision activity in an education system influences the pedagogic performance of an educator, which may have an impact on the learning outcome at schools.

Dialogic supervision introduces a distinct method of supervision from the standard model in which the pre service teacher only plays the position of a passive listener from the interaction takes place (Bailey, 2006). Following Waite (1995), dialogic supervision views the supervisory process as a model of democratic communication that positions all of the involved components equally. Therefore, it can be concluded that the actual condition between the supervisory lecturer, supervisory teacher, and pre service teacher is a partnership cooperation. Drawing on the approach model proposed by Jahanian and Ebrahimi (2013), a professional training program functions as a means of exchanging knowledge and skills between all of the involved party, namely student teacher, supervisory teachers and/ lecturers. Through a process of a dialogue with the teachers and lecturers, students can be guided to be able to reflect on their pedagogical performance starting from the teaching preparation to the process of learning evaluation (Schauber, 2015). The process of PLP reflection, therefore, is not only one way but the evaluation will be from both sides.

\section{The Benefit of Dialogic Supervision}

Generally, Burhanuddin (2005) explains that the goal of a supervision activity in an education process is to develop a better learning through sequential supervision and teaching profession improvement. The dialogic supervision model makes it easier for all parties, so program related information such as the regulations, the principles of management, and the teaching methods can be well delivered (Loiso \& McNeil, 1969, cited in Jahanian \& Ebrahimi 2013). They also assert that the effectively formed interaction can make it easier for pre service teachers to achieve the goals of the profession. In relation to this, Hasan (2002) adds that transparency in the communication between all parties in a dialogic supervision is needed to provide a room for evaluation and reflection, so it can optimally mend or improve teaching professionalism.

Hasan (2002) explains that a supervision assists and provides opportunities for the teachers to learn how to improve their competence to create the learning objectives of the learners. Specifically, it is explained that the dialogic supervision when properly implemented can benefit students in the following aspects:

1. Improving the teachers' enthusiasm in teaching and also the students' interests in learning the offered subjects.

2. Achieving the awareness and attention on the quality of education in the school among teachers, students, the principal and all related parties.

It can be concluded that a dialogic supervision can become an alternative model to accommodate the needs of communication among parties, either the chief organiser or the members.

\section{The Implementation of Dialogic Supervision}

Dialogic supervision views the supervisory process as a reservoir for the sharing of data on the objective situation discovered in the field from the perspective of all associated parties (Jahanian \& Ebrahimi, 2013). Waite and Waite (2012) also contend that critical thinking, reflection, and acceptance are all the characters that have to be created during the process, in order to develop reflective and evaluative abilities in order to attain a better program. There are three stages required to implement the dialogic supervision approach (Stoller,1996; Sullivan \& Glanz, 2005; Waite \& Waite, 2012).

\section{a. Planning}

This stage begins with identifying the school's ideal condition, to find out the emerging gaps among all parties. The supervisory lecturer, supervisory teacher, and pre service teacher discuss strategies they will take to solve the problems.

b. Field visit

In this process, field supervisory lecturer directly observes the objective condition on the field to study any potential situation that might create problems based on the discussions in the planning stage.

c. Providing Feedback

At this stage, field supervisory lecturer, supervisory teacher, and the pre service teacher meet together to reflect on the ongoing process of PLP. They can also predict the possibility for any gap in the field, other than the previously formulated problems. According to Kayoaglu (2012), the feedback session can refer to the data observation planning that has been done cooperatively by all of the parties.

During the dialogic supervision process, there are several points that need to be considered to maintain fair communication, as explained by Burhanuddin (2005) as follows:

- The supervision has to be organised with systematic preparation and planning. 
- The supervision should provide initial information about the program to the involved parties.

- The supervision is held through several techniques and methods to produce a comprehensive result.

- Supervision instruments, forms and other documents should be well-prepared.

- Reports to all related parties are expected to be made after the supervision

In detail, the dialogic model of PLP implementation adopts Waite and Waite (2012) and Schauber's (2015) proposal as explained in Figure 1.

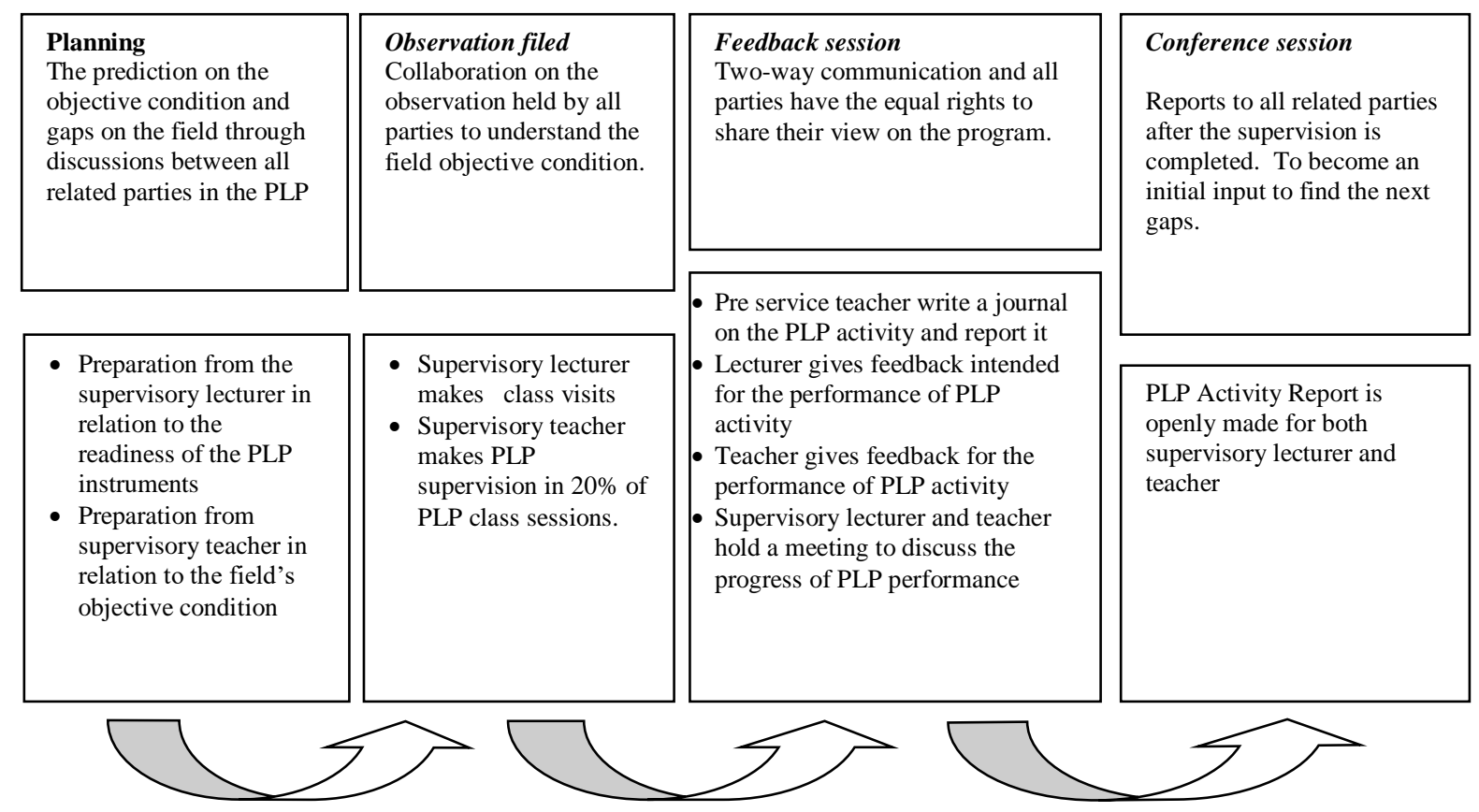

Figure 1. Diagram for the Implementation of Dialogic Supervision Model

\section{Contextualizing Teacher Education in English language Teaching}

The growing demand and interest in English teaching has been proven by the increasing number of universities and institutions offering English Education program. What makes English Education different from English studies (Non Education Program) is that it has PLP as one of the major subjects which consists of 6 credits. This is a compulsory program offering the opportunity to the university students, especially in the semester 8 to implement the knowledge they have received to either elementary, junior high, or senior high school students.

Referring to the ideal teaching and learning principles, this program is a key program for all teacher candidates for they will face with the phenomenon and complex learning problem. Therefore, English students doing PLP (pre service teachers) are expected to equip themselves with the competencies that emphasizes on the understanding of English teaching materials, mastery of English teaching methodology, and applying good English Language assessment and evaluation. In general, teachers are perceived to have the following competences: (1) Teacher as an expert of material; (2) Teacher as an expert of education; (3) Teacher as an expert of design, evaluator, and executor (Brown, 2001; Harmer, 2001). However, those three things can change due to the following factors: (1) the context of learning;
(2) the teaching experience; (3) and the teacher's background. Relevant with this, PLP will provide future teachers with hands on experiences related to the roles of a teacher.

\section{METHOD}

This research is at the initial stage of a Research and Development, which covers preliminary research, model development, model testing, and model socialization and dissemination (Borg \& Gall, 2003). In the implementation of Dialogic Supervision in PLP, there has to be a good collaboration among the supervisory lecturer, supervisory teacher, and the pre service teacher. Before starting the intervention, the supervisory lecturer provides a training to both supervisory teacher and pre service teacher on how the pre service teacher should receive their supervision and for them to do it based on the teacher education framework. Therefore, all three involved components in the research can together discuss the PLP and its implementation realisation.

\section{Respondents}

The research subjects are the pre service teacher students doing their teaching practicum in some schools in North Bandung, at two levels: Junior High School and Senior High School. However, due to the 
practicality of the research, there are only 4 preservice teachers (2 of Junior High School and 2 of Senior High School) who are randomly chosen from each school.

\section{Procedures}

This research and development is aimed to develop the dialogic supervision model to improve the performance of the English subject pre service teacher. This activity is designed in 3 (three) years with the stages, goals, and objectives shown in Figure 2.
In this initial research stage, the research is focused on the supervision model performed by both supervisory teacher and supervisory lecturer with the pre service teacher. This investigation is conducted in accordance with the arranged schedule. The result of the supervision is used as the primary data to reveal the pre service teacher supervision pattern. Besides, referring to the investigation's results, supervision model development can start by relating the existing condition with the dialogic supervision theory.

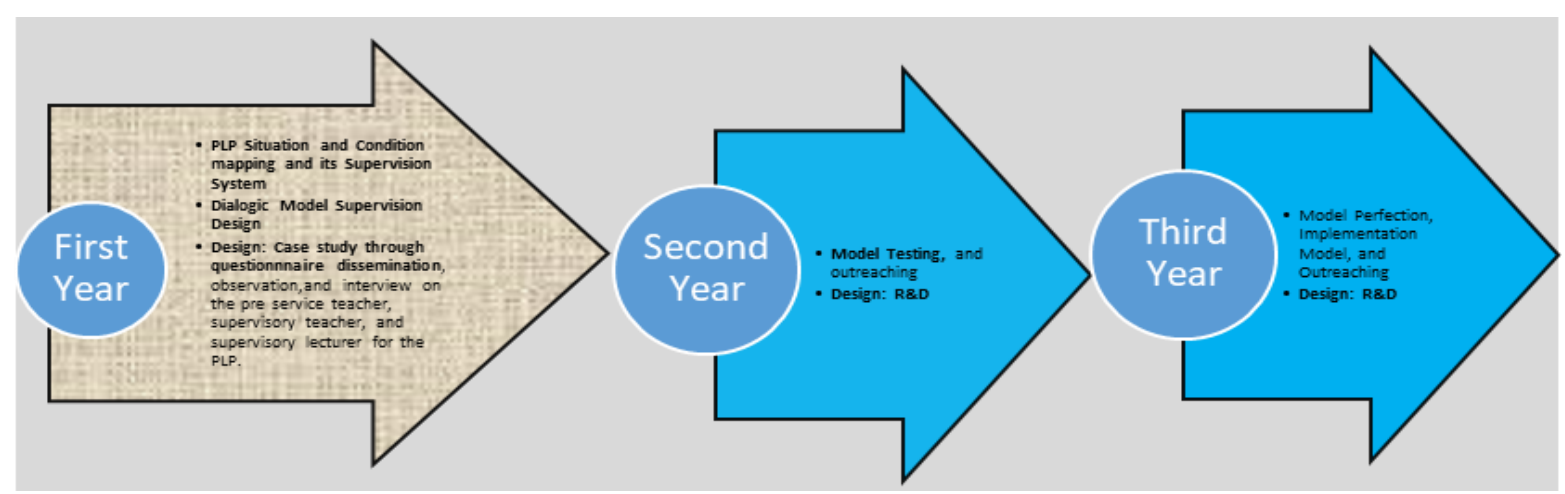

Figure 2. Research and Development Design

\section{Instruments and Data analysis}

The data were collected from three instruments: field observation, interview (with the pre service teachers, supervisory lecturer, and supervisory teacher), and document analysis (Lesson Plan and PLP guidebook). The data collected from the three instruments were analysed through several stages, such as identification, codification, pattern and relationship mapping, research result synthesis, and model construction.

The identification stage concentrated on the result of the investigation on all the aspects of pre service teacher supervision process on the Program Latihan Profesi/Professional Training Program (PLP). The video-audio recordings data from the field observation as well as interview with the three parties were transcribed to practically make sense of the process of the supervision and identify the supervision pattern.

The transcription results from the observation and interview data were then coded or categorised according to the types or material or the items listed in the supervision book. This is intended to serve as authentic evidence and as a strategy for easy coding and categorizing to answer the research questions (Smith, 1995). During the process of codification, data reduction is possible to occur for some irrelevant data to make the data become more detailed, clear, concise, and valid (Cresswell, 2012).

The next stage is the pattern and relationship mappings from all the elements based on the two previous stages of findings. In this stage, the previously found research findings were constructed into an integrated and comprehensive discussions. This activity is performed as an effort of conclusion-making and to draw logical claims from the obtained findings.
The final stage of this research was the dialogic supervision model construction in the Professional Training Program (PLP) by considering the obtained findings from the results of data collection and analysis. The proposed model is later expected to become a realdata-based effective model appropriate with the needs of teachers and the schools.

\section{FINDINGS AND DISCUSSION}

\section{Portraying the PLP supervision practices}

The findings reveal that the team of PLP supervisors (supervisory lecturers and teachers) tend to apply conventional supervision pattern, similar to what has been described by Cohen, et.al. (2013) and Waite (1995). One of the characteristics of a conventional supervision evident the data is adopting hierarchical positioning as senior domination were clear in the supervision practices as illustrated in the excerpt below:

The discussed materials are still too general and is still not enough to provide practical examples to apply in class. The discussion is more dominated by the role of the supervisors, and only a little that involves the PLP students to speak (Field Observation)

Clearly, the pre service teacher was positioned inferior to the supervisors (Pajak 1992 in Waite, 1995). In addition, the discourse of the supervisors implies power and domination over the pre service teachers. Instead of maintaining an egalitarian relation with the pre service teachers, the supervisors positioned the pre service teachers as passive receivers of information.

The materials discussed in the supervision tend to be generically related to the PLP implementation that has been run throughout the years. In the supervision 
process, there has not been any actual discussion on the cases faced by the pre service teacher on the field. Based on the observation, the discourses used by the supervision team emphasised more on mistakes made by the pre service teacher without discussing the positive side of the pre service teachers' performance (Field observation, Student Teacher \#5)

Range et al. (2013) further argues that the dominating power in the supervision process makes it difficult for the pre service teacher to develop good rapport with the team of supervisors. This has led to ineffective supervision; lack of cooperation, reflection and openness in revealing the problems hampered the pre service teacher to perform well in the classroom. Grant \& Schofield (2012) profess the same view that the wide gap between the supervisors and the supervisees may result in unsuccessful feedback during the supervisions process. Instead, this may increase the teachers' level of anxiety in performing their tasks. This is stated by one of the pre service teacher in their interview:

After teaching, we are directly asked for receiving supervision because the supervisory teacher said for them to still remember, and it is also added with the fact that the supervisory teacher always observes us every time we teach. Hmmm. it actually makes me feel nervous and afraid of making mistakes, and there is no sense of freedom. (Interview, Student Teacher\#3)

Seating arrangement can also signify power relation among the three parties. The fact that supervisory lecturer stands in front of the supervisory teacher and the pre service teacher to explain contentrelated supervision materials as if they were in a lecture, clearly shows superior-inferior relations. This type of subject positioning is in conflict with the principles of dialogic supervision (Jahanian \& Ebrahimi, 2013). In relation to this, a U-shaped seating arrangement is recommended as it places the students, supervisory teacher, and supervisory lecturer at the same level assuming equal rights to express opinions during the process of dialogic discussion (Cohen, et.al., 2013; Waite, 2004). Relevant with this, Moriarty, et.al. (2008) contend that feedback discussions are supposed to create the conditions of equal positions to allow for open experiences and knowledge sharing sessions.

Despite the conventional pattern, the sign of dialogic practices occurred during supervision process. Jahanian and Ebrahimi (2013) believes that a dialogic supervision emphasises on identifying the strengths and providing feedback for improvement in the part of the pre service teachers instead of merely evaluating the performance. This is supported by the statements of the pre service teacher with their supervisory teacher where in one of the supervision sessions a supervisory teacher explains about their strengths as follows:

Yes, approximately ... almost every time after teaching, the supervisory teacher directly asked to have a discussion on the performance. The supervisory teacher would explain the strengths of my performance and it became the point that I have to maintain for my next teaching session. Then hmm... the weaknesses were also mentioned, so I knew what I had to make better in my next teaching session. (Interview, Student Teacher \#2).

\section{The Emergence of dialogic supervision practices identified in the PLP supervision}

In addition to the findings of conventional supervision practices, the practices of dialogic supervision also have started to emerge in some schools as indicated by the setting of supervision, as well as the discourse and feedback provision.

Related to the supervision setting, both supervisors and the pre service teachers have chosen to meet outside of the school; which is not far from the school and the lecturer's office. The atmosphere of the open space creates a friendlier and a more relaxing atmosphere for the supervisors and the student teachers to discuss, yet it dissolved the gap. This is in line with one of the principles of dialogic supervision that underlines the equal position and role in the process of supervision between the team of supervisors and the pre service teachers, and they consider each other as collegial partners (Waite, 2004; Waite \& Waite, 2012). The data form the direct interview with one of the supervisors also show that equality is also felt not only between the team of supervisors and the pre service teacher, but also between the team of supervisory lecturers and the supervisory teachers can be seen in the following excerpt:

I remembered that I (a supervisory teacher), a supervisory lecturer, and a pre service teacher meets in a campus area. There we discussed quite a lot on the development of the PLP students and also discussed the PLP examination. I can understand the supervisory lecturer is busy because the person held a position, but it is evident that when we met, we immediately had an exchange of thoughts, and could give our opinion for the upcoming PLP. (Interview, Supervisory Teacher)

The practice of dialogic supervision can also be identified from the discourse of the team of supervisors who used more persuasive strategies to involve the pre service teacher in the process of discussion. Clearly, the supervisory lecturer provides the opportunity for the pre service teacher to share the obstacles they faced during the PLP before the supervisory lecturer and supervisory teacher finally evaluated their performance. For a clearer view on the use of dialogic discourse, it can be seen in the following data excerpt of conversation:

I did self-reflection by answering the tutor's statement about my strengths and weaknesses during teaching ... yes I added what continues to feel especially the difficulty in handling certain things such as children who have difficulty concentrating during the learning process. Actually given that question made me more comfortable in communicating with the tutor teacher because I was not directly blamed if there was a lack of my teaching method. (Interview, Student Teacher \#3)

Based on the field observation, the choice of communication style becomes an important element in the implementation of dialogic supervision. From one of 
the schools, it was found that the use of collegial discourse, which opens the equality as partners has proven to be effective. The supervisory lecturers and teachers share their pre service teaching experiences. The team of supervisors also maintain persuasive and interactive discourse; it has made the pre service teachers more confident to reveal their experiences during the PLP or even to ask questions to the supervisory lecturer. This way, the pattern of dialogic supervision makes teachers become more cooperative in the implementation of supervision or in a task (Jahanian \& Ebrahimi, 2013). It shows that the communication is more multidirectional among the three parties. Therefore, the process has reached a phase where the supervision has shifted to a dialogic supervision that creates equal conditions in terms of position among all parties and provides equal opportunity for them to perform the supervision (Jahanian \& Ebrahimi, 2013).

Another indicator of the emergence of dialogic supervision is feedback provision. The findings reveal that the supervisory lecturer provides feedback to the PLP students in relation to class management, teaching method, and lesson plan based on what has been reflected in the students' teaching activity journal. The journal is one of the compulsory tasks from the lecturer during the process of the PLP teaching process. However, the response provided by the lecturers, according to one of the pre service teacher respondents appear to be more theoretical to be implemented in the field.

\section{Obstacles faced during supervision}

There are a number of challenges encountered by the pre service in terms of the intensity of the supervision (the supervision schedule), the relation and communication with the team of supervisors, materials for the supervision, and feedback.

The difficulty related to the intensity of the supervision was due to supervisory lecturer's and teachers' failure to meet the arranged schedule, as revealed by the following pre service teacher during the interview:

During the program, the supervisory lecturer only visited twice, presenting the students to the school and after the program finished .... While, I actually needed some supervisions, actually for the first month of the program because there were a number of issues and problems to be supervised ... well....(Interview, Student Teacher \#6)

Another issue occurred because the supervisory teacher feels certain with the competence of the pre service teacher, so they think that supervision is not necessary:

I seldom supervise the pre service teacher because they are already smart and they are independent ... and they are from [mention the name of the institution], so they can just continue what they are ding, except if the pre service teacher tells me if there is a problem and they need to discuss it. Hmmm... it seems that there have not been any problems so far. (Interview, Supervisory Teacher)
The low intensity of the supervision has led to pre service teacher's difficulties to handle problems, particularly things related to the lesson plan design, class management, and ineffective learning strategy. They have been equipped with theoretical foundation of teaching, however the real sites could be totally different from that of the theories of language teaching (Brown, 2001; Nunan, 2003). In addition, the lack of experience made it difficult for the pre service teacher to make any decision to solve a problem in their teaching process. Therefore, they need a team of supervisors to assist them in putting the theories into practice. The confidence that supervision is one of the ways to improve the quality of teachers' teaching quality is asserted by Marshal (2009), as he deliberated that it covers the inspection activity or observation in the teachers' classrooms to observe their performance and to provide feedback to the teacher and to provide a formal and normal evaluation. Therefore, it will give a significant effect on the development of the teachers' teaching competence. The function of supervision, hence, is paramount for the improvement of teachers' competence and professionalism in teaching (Waite; 1995, Marshal;2009; Jahanian \& Ebrahimi, 2013).

It is surprising to find that the relationship between pre-service teachers and the supervisor may also become both supporting as well as inhibiting factor for successful supervision. As Waite (1995) contends that a good supervision for a program has to be flexible, practical, and effective for all parties may benefit from the practices. If they can maintain good rapport, all parties will feel comfortable to hold the supervision with any pattern of supervision under the PLP objective. Unfortunately, the majority of the pre service teacher express distances from their supervisors:

I often feel afraid for a supervision since the lecturer appears to not want me to discuss the problem the supervisor thought unnecessary to discuss in the supervision ... but this only needs to be told to the supervisory teacher. (Interview, Student Teacher \#3)

Material selection has also been another problem. During supervision session, the lecturer and the teacher only ask for general issues such as large classes, limited schedule and facility. The discussion of material development and selection to the technical issues have been overlooked in the supervision as stated by the following pre service teacher respondent. Furthermore, the pre service teachers admitted that they need assistance to develop appropriate syllabus and lesson plan as the main components in the final PLP assessment:

During the supervision I was not asked anything related to the learning topic, let alone to discuss it in specific, so the topic used for the supervision is what I think is general and not anything related to the problems that I faced or I needed to consult on. I actually wanted for the supervision materials to be more related to the lesson plan, because it is not enough if it is only done once. But it needs quite an intensity beginning from the core competence to the basic competence, and their 
derivation to the indicators and the learning objectives. Honestly, even if those have been discussed in the lecture on syllabus and lesson plan, but in practice, hmm we are still confused. (Interview, Student Teacher \#1)

Finally, lack of opportunity to articulate ideas has become the most difficult challenges in the part of pre service teachers, particularly for those experiencing conventional pattern of supervision. Responding to this, Marshal (2009) adds that research of supervision in the developed countries shows that a conventional supervision is more focused on the supervisor and not on the teachers' performance. What happened in the field is how the student teachers made their best impression on the supervisors who had higher position. Marshal also (2009) contends that in the context of teacher supervision with the direct supervisor, the supervisors are more likely to forget what they found in their observation. The supervisors are also considered emphasizing more on checking administrative tasks instead of the student teachers' actual classroom performance.

Having identified the challenges, there are a number of offered solutions for better supervision practices. First, in relation to the limited time, all parties involved should agree with the arrange schedule prior to the commencement of first supervision session. Supervision practices can also be delivered through different modes, for instance if face to face sessions appears to be difficult, this issue can be addressed through the use of social media to communicate or to provide content supervision. Similar point is also underlined by Al-Qahtani (2015) in his study, which revealed the importance of the use of technology in the effort to develop teachers' professionalism. Nowadays, social media such as Whatsapp, Line, and Email can be an alternative sites of discussion. Even face to face interaction can be practically mediated through a teleconference using applications such as Skype or Google Hangouts.

Second, to make supervision material more effective and appropriate to what is needed by the preservice teachers, it is paramount to conduct a need analysis which can be discussed among supervisors in the meeting planning for PLP supervision. Therefore, the feedback or the evaluation result from the supervisors will have a positive and significant effect in optimising the pre service teachers' performance on the field, since the evaluation is clinical and practical. Understanding the needs of pre service teachers will greatly affect their performance in their future career as English teachers in terms of subject related knowledge as well as pedagogical content knowledge (Shaughnessy \& Boerst, 2018).

\section{CONCLUSION}

This present research aims at investigating the current practices of supervision model for further development of Dialogic Supervision Model. The findings reveal that the English pre service teacher supervision pattern from some schools tends to use the conventional supervision pattern. This is shown through some indicators namely the place for supervision (formally done in the teachers' room), time of supervision (not properly scheduled), the roles of each involved parties (still hierarchical referring to the roles' positions), supervision materials (have not been directed to problem-based supervision), the discourse used (instructional-based discourse), and feedback (instant and unsustainable).

However, from the analysis results, some aspects of dialogic supervision have emerged in some schools as evident in several aspects namely the opportunity given by the team of supervisors for the pre service teachers to perform their self-reflection, equal position from all involved parties, and a more flexible place for supervision. Related to the implementation of dialogic supervision, there were some obstacles faced by the pre service teacher, such as the limited time provided by both supervisory lecturer and teacher, one-sided coordination from the team of supervisors, supervision materials that were not problem-based, which tend to be more general and repetitive (not updated). Further, one of the main problems faced by the pre service teachers were the prominent gap among the roles of the three parties, which resulted in failures to develop good rapport with the supervisors. Hence, sharing experiences and problem solving activities have not been part of the culture of the supervision process.

This study suggests for several solutions to the problems. First, arranging an activity timeline, which is organised and agreed by all parties before the implementation of the PLP. Some of the aspect listed in this activity timeline covers the supervision's schedule, objectives, and materials. An organised supervision schedule has the function to map the activities in the supervision, so it can minimise the obstacles related to the direction of the supervision process. It will also be expected to cover all of the components involved in the PLP and the competences that the pre service teacher aimed at. Further, it also calls for urgent discussion of material planning and development among the supervisory teachers and lectures as well as the preservice teachers.

\section{ACKNOWLEDGEMENTS}

This research was funded by Indonesia University of Education Grant.

\section{REFERENCES}

AL-Qahtani, H. (2015). Teachers' voice: A needs analysis of teachers' needs for professional development with the emergence of the current English textbooks. English Language Teaching, 8(8), 128-141.

Bailey, K. M. (2006). Language teacher supervision: a case-based approach. Cambridge: Cambridge University Press. 
Brown, H.D. (2001). Teaching by principles: An interactive approach to language pedagogy. NY: Longman.

Burhanuddin, Y. (2005). Administrasi Pendidikan. Bandung: Pustaka Setia. Bandung: Pustaka Setia.

Cohen, E., Hoz. R., \& Kaplan, H. (2013). The practicum in preservice teacher education: A review of empirical studies. Teaching Education, 24(4), 345380. doi: 10.1080/10476210.2012.711815

Creswell, J. W., \& Poth, C. N. (2018). Qualitative inquiry and research design choosing among five approaches. Los Angeles: SAGE.

Gall, M. D., Gall, J. P., \& Borg, W. R. (2003). Educational research: An introduction. Boston, MA: Allyn and Bacon.

Glanz, J., \& Behar-Horenstein, L. S. (2000). Paradigm debates in curriculum and supervision modern and postmodern perspectives. Westport, CT: Bergin \& Garvey.

Grant, J. \& Schofield, M.J. (2012). Managing difficulties in supervision: Supervisor's perspectives. Journal of Counseling Psychology. 59(4). 528-541.

Harmer, J. (2001). The practice of English language teahing. Cambridge: Pearson-Longman.

Hasan, I. (2011). Upaya meningkatkan kompetensi guru MIPA dalam menyusun RPP melalui supervisi akademik di SMP Negeri 15 Kota Gorontalo. Jurnal Penelitian dan Pendidikan, 8(1), 13-21.

Jahanian, R., \& Ebrahimi, M. (2013). Principles for educational supervision and guidance. Journal of Sociological Research, 4(2), 380-390. doi:10.5296/jsrv4i2.4562

Kayaoglu, M. N. (2012). Dictating or facilitating: The supervisory process for language teachers. Australian Journal of Teacher Education, 37(10), 103-117. doi:10.14221/ajte.2012v37n10.4.

Marshall, K. (2005). It's time to rethink teacher supervision and evaluation. Phi Delta, Kaplan, 87(10). 727-735
Moriarty, B., Danaher, P. A., \& Danaher, G. (2008). Freire and dialogical pedagogy: a means for interrogating opportunities and challenges in Australian postgraduate supervision. International Journal of Lifelong Education, 27(4), 431-442.

Nunan, D. (2003). Practical English language teaching. New York: Mc Graw Hill

Porniadi, F., Kardoyo, Yanto H. (2019). The pedagogical competence predicted from academic supervision: Compensation and work motivation. Educational Management, 8(1), 80-87.

Schauber, H. (2015). Using the EPOSTL for dialogic reflection in EFL teacher education. GiST Education and Learning Research Journal, 11, 118-137. doi:10.26817/16925777.290.

Shaughnessy, M., \& Boerst, T.A. (2018). Uncovering the skills that preservice teachers bring to teacher education: The practice of eliciting a student's thinking. Journal of teacher Education. 69(1), 4055. doi: 10.1177/0022487117702574

Smith, K. G., Carroll, S. J., \& Ashford, S. J. (1995). Intra-and interorganizational cooperation: Toward a research agenda. Academy of Management Journal, 38(1), 7-23.

Stoller, F. L. (1996). Teacher supervision: Moving towards an interactive approach. English Teaching Forum, 34(2), 2-9.

Sujati, S. (2015). Diagnosis hambatan praktikan D-II PGSD dalam mengaplikasikan keterampilan mengelola kelas. Jurnal Ilmiah Guru Caraka Olah Pikir Edukatif, 7(1), 25-31.

Sullivan, S., \& Glanz, J. (2005). Supervision that improves teaching: Strategies and techniques. Thousand Oaks, CA: Corwin Press.

Waite, D. (1995). Rethinking instructional supervision: Notes on its language and culture. London: Falmer Press.

Waite, S.F., \& Waite, D. (2012). Toward more democratic student teacher supervision. In Supervising student teachers, (pp. 93-106). doi: 10.1007/978-94-6209-095-8_7 